\title{
Comparative Analysis of Russian News Reporting and News Commentary in Metadiscourse Applications
}

\author{
Li Yan ${ }^{1, a}$ \\ 1 College of Foreign Languages and Cultures, Xiamen University, \\ Xiamen, China. \\ a liyan_386@163.com
}

\begin{abstract}
News reporting is a report of new events happening somewhere. While news commentary is the voice of the editor or reporter about news events and his or her instructive ideas on a social phenomenon. Metadiscourse plays a crucial role in both the two genres of news discourse. This paper selects twenty pieces of Russian news reports and news commentaries respectively to make a comparative analysis of similarities and differences of metadiscourse application and to explore its distribution and characteristics in order to enrich the application of metadiscourse and help the reading, writing and translation of Russian news at the same time.
\end{abstract}

Keywords: Metadiscourse, Russian news reporting, Russian news commentary, Contrastive analysis

\section{Introduction}

News reporting and news commentary are two important parts of newspapers, spread world events and have a significant impact on the reader. They are two important parts of newspapers, spread world events and have a great impact on readers. It makes the news reads smoother, clearer structure, while also helping news comment author self-projection views, better establish interaction between readers and authors to make text more convincing. However, metadiscourse how to help these two news styles play its discourse functions, to influence readers and dissemination of the contents of the effect, worthy of further discussion.

\section{Theoretical Framework}

\subsection{Defined metadiscourse}

For "metadiscourse" concept, different scholars have different definitions. But "metadiscourse is to organize discourse, expressing the author's view of discourse, the reader is directed to a method of reacting" This view has been accepted by most people (Xu Jiujiu 2010). We believe that this definition is more comprehensive, useful in the present study. Recent studies people metadiscourse this linguistic phenomenon more and more attention. So far, the research metadiscourse discourse, especially on metadiscourse in a particular discourse, there is a vast space. As noted Hyland, be descriptive empirical research in a variety of genres, context of improvement and development metadiscourse theoretical model is important. Therefore, this article focuses on the Russian news reporting and news commentary of these two genres Metadiscourse usage.

\subsection{Classification Metadiscourse}

To date, most researchers classification of metadiscourse have adopted dichotomy. Kopple (1985) and Crismore(1993) make metadiscourse into textual metadiscourse and interpersonal metadiscourse two categories. Later, Hyland \& Tse (Hyland, K. \& P. Tsc. 2004) further amended the metadiscourse classified as interactive resources and interactional resources categories, The former is designed to focus on the internal structure of discourse and language fluency to guide the reader to understand the information conveyed in text, while the latter focuses on helping authors to express their views and attitudes and closer to the reader, the reader quickly admission to the authors. Its classification is mainly from the perspective of authors and readers to interact metadiscourse to explore the role of this feature and news reporting and news commentary characteristics coincide. In view of this, the analytical framework of this study using Hyland \& Tse (2004) metadiscourse sort mode, as shown in Tab1: 
Tab1:metadiscourse classification scheme

\begin{tabular}{|c|c|c|}
\hline category & subcategory & Russian example \\
\hline \multirow{5}{*}{$\begin{array}{l}\text { interactive } \\
\text { resources }\end{array}$} & transitions & $\begin{array}{c}\text { тем более, однако, более } \\
\text { того }\end{array}$ \\
\hline & $\begin{array}{l}\text { frame } \\
\text { markers }\end{array}$ & $\begin{array}{l}\text { во-первых, во-вторых, } \\
\text { потом, в конце концов }\end{array}$ \\
\hline & $\begin{array}{l}\text { endophoric } \\
\text { markers }\end{array}$ & $\begin{array}{c}\text { как впереди, как выше; } \\
\text { как раньше }\end{array}$ \\
\hline & evidentials & как говорят, известно, \\
\hline & $\begin{array}{l}\text { code } \\
\text { glosses }\end{array}$ & т.е., другими словами, \\
\hline \multirow{5}{*}{$\begin{array}{l}\text { interaction } \\
\quad \text { al } \\
\text { resources }\end{array}$} & hedges & $\begin{array}{c}\text { может, может быть, в } \\
\text { какой-то мере, в } \\
\text { некотором смысле }\end{array}$ \\
\hline & boosters & $\begin{array}{c}\text { конечно, очевидно, ясно, } \\
\text { несомненно; без } \\
\text { сомнения } \\
\end{array}$ \\
\hline & $\begin{array}{l}\text { attitude } \\
\text { markers }\end{array}$ & $\begin{array}{c}\text { жаль, к сожалению, к } \\
\text { радости }\end{array}$ \\
\hline & $\begin{array}{l}\text { engagement } \\
\text { markers }\end{array}$ & ты, вы, дорогие читатели \\
\hline & $\begin{array}{c}\text { self- } \\
\text { mentions }\end{array}$ & я, МЫ \\
\hline
\end{tabular}

\section{Corpus collection and research methods}

\subsection{Corpus source}

This study is based on analysis and appraisal of corpus. To ensure homogeneity of corpus selection, within a certain range of the corpus reliable reasoned qualitative and quantitative analysis, except a very few examples of the vast majority of our analysis is an excerpt from a larger corpus Russia circulation, readership groups broader "public" of the press: "Аргументы и факты"(Arguments and Facts) and a high reputation for the intelligentsia of "high quality" newspaper: "Известия"(Izvestia) real-time and part of the Itar-Tass news on the official website, Xinhua Russian news reporting and news commentary discourse. This paper analyzed corpus is the mainstream newspapers from 2015 randomly collected news reporting and the comments made by Russian news 20, a total of 41468 words (7080 characters discourse Russian news reporting, Russian news commentary text 11409 words).

\subsection{Data collection and analysis}

We first Table 1 metadiscourse sort mode corpus metadiscourse classified label, then use Kconcordance retrieval tools and statistical methods to count by hand the various metadiscourse corpus. After the first, corpus processing into plain text format through the corpus retrieval and statistical packages. Because of metadiscourse judgment because the context in which there is a big difference, so we in the Microsoft Office Word environment of each news article was previously published reporting and news commentary determine the method adopted to ensure the accuracy of judgment, and conducted three careful proofreading. According to Hyland (2008) classification metadiscourse tagging and classification, and use overall usage SPSS17. 0 single metadiscourse and metadiscourse statistics and analysis. In view of the news reporting and news commentary capacity due to differences in content and form caused by different, when comparing the two metadiscourse frequency of use, we follow every 10,000 words calculated to ensure comparability.

\section{The research result}

After a review of news reporting and news discourse metadiscourse callout frequency of occurrence statistics (see

Table 2), we found that the words are frequently used element means in the news reporting and news commentary. All kinds of metadiscourse 20 news discourse discourse markers appear in a total of 173, 244 per ten thousand words, metadiscourse 20 News Reviews Discourse discourse markers appear in a total of 499, 437 per ten thousand words. This study once again proves the universality metadiscourse use. At the same time that the use of news corpus guided metadiscourse than interactive metadiscourse; and news commentary discourse in interactive metadiscourse guided metadiscourse more than the words. In addition, data from the statistical point of view, whether it is guided metadiscourse, or interactive metadiscourse, the frequency of occurrence, the news commentary texts were higher than the news discourse.

Table 2 Russian news reporting and news commentary metadiscourse overall statistical results

\begin{tabular}{|c|c|c|c|c|c|c|}
\hline \multirow{2}{*}{$\begin{array}{c}\text { Metadiscourse } \\
\text { category }\end{array}$} & \multicolumn{3}{|c|}{ Russian news reporting } & \multicolumn{3}{c|}{ Russian news commentary } \\
\cline { 2 - 7 } & Frequency & $\begin{array}{c}\text { Per Ten } \\
\text { thousand }\end{array}$ & $\%$ & Frequency & $\begin{array}{c}\text { Per Ten } \\
\text { thousand }\end{array}$ & $\%$ \\
\hline $\begin{array}{c}\text { interactive } \\
\text { resources }\end{array}$ & 112 & 158.2 & 64.7 & 198 & 173.5 & 39.7 \\
\hline $\begin{array}{c}\text { interactional } \\
\text { resources }\end{array}$ & 61 & 86.2 & 35.3 & 301 & 263.8 & 60.3 \\
\hline Total & 173 & 244.4 & 100 & 499 & 437.3 & 100 \\
\hline
\end{tabular}


We statistics the frequency of news reporting and news commentary discourse guided and interactive metadiscourse various secondary category. News discourse, more frequent use were metadiscourse: transitions (19.2\%), evidentials (14.3\%), endophoric markers (12.7\%), frame markers (11.1\%); The news commentary discourse, using more metadiscourse were: boosters $(20.8 \%)$, self-mentions $(20.4 \%)$, transitions $(12.2 \%)$, frame markers $(11 \%)$.

Is there a significant difference to further examine news reporting and news commentary metadiscourse use tools, our data were used SPSS16.0 T test. We turn first to the news reporting and news commentary discourse guided and interactive metadiscourse frequency comparison, as shown in Table 3: Russian news reporting and news commentary texts using guided metadiscourse and interactive on metadiscourse there are significant differences (Sig. (2tailed $)=.021<0.05),($ Sig. $(2$-tailed $)=.000<0.05)$.

Table 3: news reporting and news commentary discourse guided and interactive metadiscourse frequency $\mathrm{T}$ test

\begin{tabular}{|c|c|c|c|}
\hline $\begin{array}{c}\text { Metadiscourse } \\
\text { category }\end{array}$ & T value & df & $\begin{array}{c}\text { Sig.(2- } \\
\text { tailed) }\end{array}$ \\
\hline interactive resources & -3.712 & 4 & .021 \\
\hline interactional resources & -38.353 & 4 & .000 \\
\hline
\end{tabular}

Then, we were on the news reporting and news commentary discourse metadiscourse two categories of frequency of use $\mathrm{T}$ test results are shown in Table 4. Statistics showed that news reporting and news commentary: "frame markers, endophoric markers, code glosses, boosters, attitude markers, engagement marker and self- mentions" several areas showed significant differences. News reporting and news commentary in: "transitions, evidentials, hedges" areas showed no significant differences.

Table 4: news reporting and news commentary discourse guided and interactive metadiscourse two categories frequently used $\mathrm{T}$ test

\begin{tabular}{|c|c|c|c|}
\hline Metadiscourse category & $\mathrm{t}$ & $\mathrm{df}$ & Sig. \\
\hline transitions & -1.485 & 4 & .212 \\
\hline frame markers & -5.196 & 4 & .007 \\
\hline endophoric markers & 4.540 & 4 & .010 \\
\hline evidentials & 1.732 & 4 & .158 \\
\hline code glosses & -4.454 & 4 & .011 \\
\hline hedges & -1.979 & 4 & .119 \\
\hline boosters & -16.083 & 4 & .000 \\
\hline attitude markers & -5.444 & 4 & .006 \\
\hline engagement markers & -3.959 & 4 & .017 \\
\hline self- mentions & -16.083 & 4 & .000 \\
\hline
\end{tabular}

\section{Conclusion and Discussion}

\subsection{Russian news reporting with the same point metadiscourse use of news commentary}

Chinese and American Journalism Review in metadiscourse to show the use of a certain commonality. Specifically in the following areas:

(1) guided metadiscourse secondary category, "code glosses, hedges, attitude markers and engagement markers" were lower frequency of use in news reporting and news commentary. "code glosses" use in news reporting and news commentary in frequency rather to indicate the author's prediction of existing knowledge to the reader, to help the reader understand the text.

(2) "transitions" are more frequent means of meta discourse news reporting and news commentary discourse appears, marked as such focuses on the internal structure of the organization and connection discourse that discourse more coherent, more to convince content force to help the reader more quickly understand what the author expressed that the meaning of the proposition, as well as the author's point of view the development of turn of events in a more logical way to show, in order to achieve the purpose of writing.

\subsection{Differences discourse using the Russian news reporting and comments Meta}

News reporting and news commentary as two different news genres, they have their own unique characteristics and stylistic writing principles, therefore, in the use of metadiscourse show some differences.

(1) Due to Russian news reporting and news commentary on the writing features differences in the number of both genres in use in the meta-discourse and very different frequency. Russian news reporting, guided metadiscourse frequently used than interactive metadiscourse. This is because the news requires rigorous discourse coherence, while being guided metadiscourse have this feature, which helps the reader to the author or speaker indicate their discourse in the construction process of consciousness, to help the reader understand the text processes and author the purpose and emotion. So we found the extensive use of Russian news reporting guided metadiscourse. The main purpose is to demonstrate the author's news review its position on an issue, to persuade readers to agree with their views Motivation. This requires the author to focus on communicative meaning of the article, the authors establish an appropriate relationship - reader, the primary means to achieve this is to use interactive elements of discourse, therefore, interactive metadiscourse comments in the news more frequently used than guided metadiscourse discourse. Moreover, by independent sample T-test, using guided metadiscourse display and interactive metadiscourse there 
are significant differences (Sid. (2-tailed) $=<0.021,0.000$ $<0.05)$ in the news and news commentary.

(2) require authors to report the news content remain absolutely neutral, faithful and objective, does not require authors to express their attitude to events or mapped. The news comment requires authors to express their views and attitudes of events, and disseminate their views and to influence the reader to accept. Thus, the data show that from two classification point of view, "Boosters, attitude markers, engagement markers and self- mentions" the use of lower frequencies in the news, use the comments in the news more than in the news. And by independent sample Ttest, displaying news stories and news review "boosters, attitude markers, engagement markers and self- mentions" use showed a significant difference (Sid. (2-tailed) <0. 05).

(3) Notwithstanding Journalist professional make metadiscourse having authority in the use of these two genres, but different news genres such as purposeful creation of news commentary and news reporting there are differences, and the authors have different writing style, so its metadiscourse preferences and choices will be different.

\section{Acknowledgments}

This research topic is sponsored by Fujian Social Sciences Planning Program (No. 2013C082), Constructing the Test System of Professional Certification in Interpretation, and National Social Science Fund (No. 13BYY043), Xiamen University Fund for Prospering Philosophy and Social Science (No. 0650-Y07200).

\section{References}

[1] Hyland, K. \& P. Tsc. Metadiscourse in academic writing: A reappraisal [J] Applied liyuistics 2004 25: 156-177.

[2] Xu Jiujiu, modern Chinese text linguistics plant [M] Beijing: The Commercial Press, 2010. 